and to the constant inspiration of his own work. It cannot be an easy task to succeed Prof. Hardy; but we can feel confident that the high tradition associated with the Sadleirian chair will be fully maintained.

\section{Prof. E. R. Gilliland}

Prof. Edwin Richard Gillilland, professor of chemical engineering at the Massachusetts Institute of Technology, has been awarded the Leo Hendrick Baekeland Award of the North Jersey Section of the American Chemical Society, "for outstanding achievement in the fields of heat transmission, diffusion, distillation, and high-pressure synthetic chemistry". The award, consisting of 1,000 dollars in cash and a gold medal, is to be given biennially to an American chemist less than forty years of age in recognition of accomplishments in pure or industrial chemistry, and was founded to commemorate the technical and industrial work of the late Dr. Baekeland. Prof. Gilliland, who is thirty-six, is at present working in the Office of Scientific Research and Development, Washington, D.C. $\mathrm{He}$ is known as an advocate of the maintenance of a post-war synthetic rubber industry in the United States as essential to the national interest. Prof. Gilliland joined the teaching staff at the Massachusetts Institute of Technology as instructor in 1934, and in 1944 was made a full professor.

\section{Prestwich Prize of the Geological Society of France}

Prof. W. B. R. KInG, Woodwardian professor of geology in the University of Cambridge, has been awarded the Prestwich Prize of the Geological Society of France. This prize is the only one which the Society can give to a non-member, and has been given to Prof. King in recognition of his distinguished researches and also for his services to France in "la géologie militaire" during the War of 1914-18 and 1939-45 as geological adviser to the British Army.

\section{Medal of the Liverpool Geological Society}

The Liverpool Geological Society has awarded its medal to Dr. Douglas A. Allan, director of the Royal Scottish Museum, Edinburgh, in recognition of his original geological work, mainly on problems connected with the structure and petrology of the Highland Border of Scotland and Angus. The award is also an acknowledgment of the great services rendered to the Society by Dr. Allan during the fifteen years he spent in Liverpool as director of the City museums. He has edited its Proceedings for fourteen years, and by his lectures and writings has done much to develop and extend an interest in geological science which has been of great benefit to the Society.

\section{Antonin Bělohoubek (1845-1910)}

THE centenary of the birth of the elder of the brothers Bellohoubek falls on April 28. Overcoming initial disabilities, both these Czechs became distinguished chemists and influenced the progress of science in Central Europe. Born at Jeřice in Bohemia, Antonín Bèlohoubek was the pupil of Balling and began his scientific career as a demonstrator at the Prague Technical College in 1865. He was appointed docent in 1871 and professor of applied chemistry and the technology of fermentation in 1880. In this field he was a pioneer in utilizing the microseope to study biochemical problems. His published researches, mostly conducted during the 'seventies and 'eighties of last century, relate mainly to contemporary analytical procedure. From chemical and bacteriological investigations of thermal and river waters he was led to make geological surveys, and to take an interest in water purification and the disposal of industrial fluids.

Antonín Bělohoubek came before the general public in Central Europe in 1887 during the controversy concerning the genuineness of certain old Czech manuscripts found at Kraluv Dvůr in 1818, for he was the expert called in to make the microscopic and chemical examination. He was also the first to show that chloroform could not be obtained from methyl alcohol by the use of bleaching powder. Later, he became director of the chemical section of the Austro-Hungarian Patent Office in Vienna, but eventually returned to Prague, where he died in 1910. His brother, Augustus Bělohoubek (18471908), became lecturer in pharmacy at the Prague Technical College and is best known for his com. prehensive survey of the solubility of organic eom. pounds. He also wrote a treatise on drugs that had a considerable vogue towards the end of last century.

\section{Exchange of Diagrams and Data between Radio. therapy Centres}

Medical physics is rapidly expanding into an important and well-defined branch of applied physics. At the present stage of development much informa. tion is becoming available for everyday use in hospitals, but the information is scattered through a number of journals and sometimes difficult of access. Of particular importance is the distribution of radiation throughout the soft tissues of a patient during irradiation with high-voltage X-rays or gamma rays. This distribution of radiation is a complex function of the physical conditions, and recently Prof. W. V. Mayneord published a set of X-ray isodose curves giving data of direct practical applica. tion. At a meeting of the Hospital Physicists' Association it was suggested that this idea might be applied to teleradium isodose curves, and to other data. It was thought that often graphs and diagrams which appear in the literature were too small to be useful, and that many workers would like to have full-size copies of the originals. In addition, various institutions accumulate diagrams, nomograms, and data for their own use, which would be very useful to others if an interchange of copies could be arranged.

The Hospital Physicists' Association therefore appointed a sub-committee with Dr. John Read, of the London Hospital, Whitechapel Road, London, E.1, as secretary. This sub-committee has collected lists of diagrams, data, etc., which institutions are willing to lend for reproduction, and prepared a catalogue of copies which can be supplied. The catalogue includes books not easily obtainable, a short loan of which can be arranged. Some idea of the contents of the catalogue may be gathered from the fact that it covers isodose curves of a large variety of size of field and other conditions; distributions of energy in X-ray spectra ; isodose curves around radium tubes and needles of various sizes, and the distribution and amounts of radium to be used to obtain uniform fields in various conditions; photo-electric absorption coefficients in various elements; energy absorption in water and other biological modia; and tables of electronic functions. 